\title{
"Man får hjälp då man behöver" - äldre närståendevårdtagares vårdval ur ett livsloppsperspektiv
}

\author{
Sarah Åkerman ${ }^{1}$, Fredrica Nyqvist ${ }^{1}$ och Mikael Nygård $^{1}$ \\ ${ }^{1}$ Socialpolitik, Fakulteten för Pedagogik och välfärdsstudier, Åbo Akademi, Vasa
}

\begin{abstract}
Privatiseringens, marknadiseringens och närståendevårdens betydelse ökar i den finländska äldreomsorgen. Det finns ett behov av att studera hur förändringarna påverkar vårdtagare och anhöriga. Temat för den här artikeln är närståendevårdtagares vårdval. Enligt livsloppsperspektivet ses åldrande som en livslång process. Ett livslopp påverkas av de begränsningar och möjligheter som styr individens val och handlingar i en specifik historisk och social kontext. I studien har sju vårdtagare intervjuats med kvalitativa semistrukturerade intervjuer. Syftet var att studera äldre närståendevårdtagares vårdval ur ett livsloppsperspektiv. Studiens frågeställningar var: hur kan bakgrunden till närståendevårdtagarnas vårdval förstås ur ett livsloppsperspektiv? Vad har vårdtagarna för tankar om framtiden? Resultaten visade att valet av närståendevård upplevdes som naturligt, dels som en följd av den nära relationen till vårdaren och dels på grund av delvis negativa attityder till formell äldreomsorg. Vårdtagarna oroade sig för närståendevårdarens hälsa och framtida vårdarrangemang. Studien bidrar med kunskap om äldreomsorgen ur vårdtagares perspektiv.
\end{abstract}

\section{Inledning}

Den demografiska utvecklingen i kombination med politiska och ekonomiska förändringar leder till att äldreomsorgen genomgår en omorganisering i Finland. Den utökade privatiseringen, marknadiseringen och betoningen på närståendevård innebär förändringar i vem som erbjuder vården och vem som finansierar den (Anttonen \& Meagher 2013; Van Aerschot 2014). Dessa förändringar kan ses som ett steg bort från den klassiska nordis- ka välfärdsmodellen mot en mer nyliberal och konservativ modell (Anttonen \& Häikiö 2011; Karsio \& Anttonen 2017). Denna utveckling kommer till uttryck bland annat i form av större satsningar på närståendevård. Den ökade betoningen på närståendevård kallas ibland för refamilisering, vilket avser förskjutningen av vårdansvaret för äldre från offentlig äldreomsorg tillbaka till familjerna. Refamiliseringen sker efter en längre tids omfattande, universell och offentligt producerad äldreomsorg som byggts upp från 1950-talet fram till 1990-talet, 
då nedskärningar började i Finland (Anttonen 2009). Den offentliga sektorn är fortfarande omfattande, men de närståendes roll antas växa allt mer då service skärs ner trots att andelen äldre ökar (Van Aerschot 2014). Majoriteten av äldre föredrar dock offentliga tjänster framom anhörigas hjälp (Van Aerschot 2014; Vilkko m.fl. 2014).

Inom den nordiska äldreomsorgen tycks det tidigare sociala medborgarskapet med universella sociala rättigheter ha fått ge plats för ett aktivt medborgarskap, där ledord såsom ansvar, valfrihet och självbestämmanderätt dominerar diskussionen (Anttonen \& Häikiö 2011). Man utgår från att äldre vill och kan planera sin vård själva efter sina behov. Den kritik som har förts fram mot ett sådant synsätt är bland annat att denna sorts äldreomsorgspolitik lämpar sig för äldre som är friska och ekonomiskt välbärgade, men att den däremot inte är lika anpassad för andra grupper av äldre. Häikiö, Van Aerschot och Anttonen (2011) konstaterar att det faktum att många äldre befinner sig i en fysiskt, socialt och ekonomiskt mer utsatt position än andra samhällsgrupper förbises i den nya diskursen om det aktiva medborgarskapet. Det finns äldre som saknar förmågan att planera sin egen vård och service. Valfriheten har också ifrågasatts eftersom valet många gånger enbart står mellan privata aktörer och anhöriga som en följd av nedskärningar i den offentliga omsorgen. Forskning från Sverige (Ulmanen \& Szebehely 2015) visar att informell vård ökar speciellt i lägre samhällsklasser. Det skapar i sin tur en dubbel ojämlikhet, eftersom vårdbehovet drabbar både vårdtagaren och dennes anhöriga. Forskarna poängterar ändå att anhörigas insatser har ökat i alla samhällsgrupper som en följd av nedskärningar.

Enligt en enkätundersökning i Finland utförd bland 75 år fyllda och äldre hemmaboende ansåg 14 procent av de äldre att de inte fick tillräckligt med hjälp och service. Av dessa 14 procent ansåg 38 procent att orsaken till att de inte fick tillräckligt med hjälp var höga servicekostnader, medan knappt en tredjedel upp- levde att själva anskaffningen av hjälp var komplicerad (Van Aerschot 2014, s. 128). Enligt en annan studie utförd i Finland baserad på samma enkätundersökning visade resultaten att det främst var äldre med högre utbildning, ekonomi och bättre hälsa som använde sig av privata hemvårdtjänster, medan äldre med svagare ekonomi, lägre utbildningsgrad och sämre hälsa använde offentlig hemvård. De äldre som var mest sjuka använde en kombination av privata och offentliga tjänster, vilket väcker frågan huruvida offentlig service inte längre räcker till för omfattande vårdbehov (Puthenparambil, Kröger \& Van Aerschot 2015).

I forskning om närståendevård har uppmärksamheten hittills varit riktad främst på vårdarnas situation, medan vårdtagarnas upplevelser är ett mindre utforskat område (Zechner \& Valokivi 2009). Vårdtagare ses ofta som passiva objekt trots att även vårdmottagande är en aktiv handling (Twigg 2000; Dunér 2007). Att behöva vård innebär att en individ inte klarar sig själv utan hjälp. Behovet leder till att den vårdbehövande måste förhandla och påvisa sitt beroende av hjälp, vilket kan upplevas som motstridigt i dagens samhälle där självständighet är en rådande norm. En studie om äldres vårdpreferenser $\mathrm{i}$ en svensk välfärdskontext visade att deltagarna inte ville vara en börda för varken samhället eller anhöriga (Gunnarsson 2009). En annan studie om äldres vårdpreferenser i Sverige visade att deltagarna var rädda för att förlora sin identitet och värdighet genom att bli beroende av hjälp från vårdare som inte känner dem (Harrefors, Sävenstedt \& Axelsson 2009).

Syftet med denna artikel är att lyfta fram en viktig aspekt $\mathrm{i}$ utvecklingen av den finländska äldreomsorgen genom att studera äldre närståendevårdtagares upplevelser av sina vårdval. Frågeställningarna är: hur kan bakgrunden till närståendevårdtagarnas vårdval förstås ur ett livsloppsperspektiv? Vad har vårdtagarna för tankar om framtiden? Vi använder livsloppsperspektivet som en teoretisk referensram för att analysera hur vårdtagarnas vårdprefe- 
renser kan kontextualiseras i deras livslopp. Vi utgår från att närståendevård är en unik vårdform dels för att vårdformen ofta baserar sig på ett nära förhållande vårdtagaren och vårdaren emellan som sträcker sig över tid, och dels för att närståendevård är en form av vård där en icke-vårdutbildad anhörig ingår ett vårdavtal med kommunen.

Oss veterligen har fokus inte varit på vårdpreferenser i tidigare kvalitativ forskning om närståendevårdtagare i Finland. Vi känner inte heller till att livsloppsperspektivet skulle ha tillämpats i forskning om närståendevård i Finland. Närståendevård finns i alla åldersgrupper, men vår studie är avgränsad till äldre vårdtagare som vårdas av i huvudsak äldre närståendevårdare.

\section{Teoretisk referensram och centrala begrepp}

Vi vill med vår studie tillföra kunskap om närståendevård genom att inkludera en hittills relativt outforskad målgrupps perspektiv, nämligen vårdtagarnas. Livsloppsperspektivet möjliggör att vi kan förankra deras erfarenheter i ett dels subjektivt livslopp, en dels gemensam historia vårdtagaren och vårdaren emellan och slutligen i en samhällelig kontext där de jämnåriga deltagarna i studien representerar en generation som upplever liknande historiska skeenden under samma livsperiod. Vi vill särskilt studera hur äldreomsorgens utveckling och utformning idag influerar vårdtagarnas vårdval.

Inom den socialgerontologiska forskningen har livsloppsperspektivet fått ett allt större genomslag (Alley, Putney, Rice \& Bengtson 2010). Teorin möjliggör studier av en individ eller en kohort i en kontext som sträcker sig över tid. Livsloppsperspektivet har tillämpats speciellt i kvantitativ longitudinell forskning, men även i till exempel kvalitativa livsberättelser (Mayer 2009). Enligt Elder Jr., Kirkpatrick Johnson och Crosnoe (2003) finns det fem viktiga principer att utgå från i livsloppsperspektivet. Åldrande och utveckling ses som en livs- lång process (life-span development), där individer agerar och gör val inom ramen för de möjligheter och begränsningar som den historiska och sociala kontexten omfattar (agency). En individ påverkas av tid och plats (time and place) och i vilket skede viktiga vändpunkter inträffar (timing). En individs livslopp påverkar och påverkas av andras livslopp (linked lives). I vår studie utgår vi inte från principerna i detalj, utan väljer att betrakta livsloppsperspektivet som en övergripande förståelseram för att studera vårdtagarnas vårdval.

\section{Närståendevård}

Enligt finländsk lagstiftning definieras närståendevårdare som "en närstående till den vårdbehövande eller någon annan som står den vårdbehövande nära och som ingått ett avtal om vård" (Lag om stöd för vård 937/2005). I artikeln inkluderar vi även vårdare utan avtal i begreppet närståendevårdare. Avtalsbaserad närståendevård omfattar tjänster såsom vårdarvode, ledighet, pensions- och olycksfallservice samt socialservice för vårdaren. Vårdarvodets storlek varierar mellan kommuner och beroende på vårdbördan som delas in i olika klasser. År 2017 varierade minimivårdarvodet mellan 392,00-926,80 euro (SHM 2016a). Närståendevårdare med avtal har rätt till minst två dagars ledighet i månaden.

Enligt en undersökning om avtalsbaserad närståendevård i Finland år 2012 var ungefär 70 procent av vårdarna kvinnor. Ungefär hälften av vårdarna vårdade sin make/maka. Över hälften av vårdarna hade fyllt 65 år, medan en fjärdedel hade fyllt 75 år. Av vårdtagarna hade 67 procent fyllt 65 år. Både äldre vårdare och äldre vårdtagare var med andra ord i majoritet. I Finland uppskattas 350000 vara närståendevårdare, medan enbart cirka 40500 av dessa har ett vårdavtal (SHM 2014, s. 21-23).

Avtalsbaserad närståendevård besparar de finländska kommunerna cirka 1,3 miljarder euro i året i jämförelse med om samma vårdbehov skulle ha tillgodosetts på annat sätt 
i offentlig regi. Social- och hälsovårdsministeriet [SHM] har som målsättning att utöka närståendevården från nuvarande ca 40500 till 60000 fram till år 2020 (SHM 2014, s. 11). Närståendevård är ett område som statsminister Juha Sipiläs regering vill satsa på i de rådande åtstramningstiderna. Regeringen har beviljat ett nationellt spetsprojekt (2016-2018) 30 miljoner euro för att utveckla närståendevården och äldres hemmaboende. Projektets målsättningar är bland annat att starta upp så kallade närståendevårdcenter, främja närståendevårdares möjligheter att ta ut ledigheter och erbjuda hälsoundersökningar för närståendevårdare (SHM 2016b).

I Finland visar en undersökning om avtalsbaserad närståendevård att uppskattningsvis 26-46 procent av vårdtagarna skulle få institutionsvård om de inte hade en närståendevårdare (Linnosmaa, Jokinen, Vilkko, Noro \& Siljander 2014, s. 15). Den stora vårdbördan och det faktum att enbart hälften av närståendevårdarna tar ut sin lagstadgade ledighet innebär en risk för utmattning. Många närståendevårdare önskar hemlik avlösarservice, men ofta erbjuds enbart kortvarig institutionsvård för vårdtagaren under närståendevårdarens ledighet. Det ekonomiska stödets storlek, tillgång till stödet samt andra stödtjänster för närståendevård varierar beroende på kommun (SHM 2014). Samtidigt finns det förhoppningar om att den planerade social- och hälsovårdsreformen ska utjämna ojämlikheterna mellan kommunerna (Vård- och landskapsreformen u.å.).

\section{Metod och material}

Studien är en avgränsad, omarbetad version av en magisteravhandling vars syfte var att studera äldre vårdtagares upplevelser av närståendevård och åldrande genom att tillämpa livsloppsperspektivet och den sociala utbytesteorin. Den här artikeln, vars data härstammar ur ovan nämnda avhandling, är en fall- studie som baserar sig på kvalitativa intervjuer (Esaiasson, Gilljam, Oscarsson \& Wägnerud 2007). Kriterierna för deltagande i studien var svenskspråkiga äldre över 63 år, som inte led av minnessjukdomar och som vårdades av en närstående antingen med eller utan vårdavtal. Urvalet gjordes av en kontakt vid Folkhälsan, som är en allmännyttig social- och hälsovårdsorganisation verksam i hela Svenskfinland (Folkhälsan u.å.).

Informanterna var i åldern 71-80 år och alla utom en informant vårdades av närståendevårdare med vårdavtal. Fem av informanterna var kvinnor och två var män. Fem av sju vårdades av sin make/maka. En informant blev vårdad av sitt syskon, medan en annan vårdades av både sin partner och sin dotter. En informant bodde på servicehus och de övriga i egna hem. En informant vistades regelbundet på en bäddavdelning för att avlasta närståendevårdaren, medan en annan informant vistades på en bäddavdelning någon gång $i$ året. Tre informanter fick hemvårdtjänster i varierande utsträckning. Fyra av informanterna bodde på landsbygden och tre i stadsmiljö.

Vårdperiodens längd varierade mellan 3 och 51 år. Makarna hade varit gifta mellan 50 och 60 år. Samtliga informanter bodde tillsammans med sin vårdare, förutom i det fall där informanten blev vårdad av både sin partner och dotter, där enbart partnern bodde tillsammans med informanten. Orsaken till informanternas vårdbehov varierade, men inkluderade till exempel stroke, förlamning, synskador och nedsatt balanssinne. Intervjuernas längd varierade mellan 35 och 88 minuter. På grund av informanternas nedsatta funktionsförmåga utfördes samtliga intervjuer i deras hem. Det visade sig vara svårt att intervjua informanterna utan närståendevårdarens närvaro vilket kan tänkas påverka resultaten i viss mån. Informanten verkade i en del fall känna sig tryggare ifall närståendevårdaren närvarade, och en del informanter oroade sig för att inte kunna svara"rätt" på frågorna. Fyra av intervjuerna skedde därför 
i närståendevårdarens närvaro i varierande utsträckning. Närståendevårdarens kommentarer har inte använts i analysen.

I studien utfördes sju kvalitativa semistrukturerade intervjuer, vilket innebär att forskaren följer en intervjuguide samtidigt som följdfrågorna och ordningsföljden på frågorna anpassas efter informantens svar (Bryman 2011). Intervjuerna bandades in och transkriberades kort efter intervjutillfället, vilket är i enlighet med Kvale och Brinkmanns (2009) rekommendationer. Materialet analyserades med hjälp av kvalitativ innehållsanalys i dataprogrammet NVivo10. I analysen tillämpades främst en induktiv ansats där materialet styrde kategoriseringen (Kvale \& Brinkmann 2009), men vissa deduktiva inslag ingick eftersom intervjuerna kretsade kring tre huvudkategorier: vård, livslopp och reciprocitet. Frågorna kretsade kring till exempel informanternas bakgrund, deras relation till närståendevårdaren, för- och nackdelar med att få närståendevård samt vårdtagarens förmåga till reciprocitet med närståendevårdaren. Underkategorierna skapades utgående från informanternas berättelser. I den här omarbetade studien är syftet och frågeställningarna inte de samma som i magisteravhandlingen och utgör därmed en sekundär analys. Kategoriseringen skedde efter flera genomläsningar av intervjuerna och efter diskussion mellan intervjuaren och en annan forskare.

Informanterna deltog i intervjun frivilligt. De blev tillfrågade av kontaktpersonen på Folkhälsan och gav därefter tillåtelse att överlämna sina kontaktuppgifter till intervjuaren. Vi har säkrat informanternas anonymitet genom att exkludera kännspaka uttryck eller ord och genom att exkludera namn på orter eller personer ${ }^{1}$. För studien behövdes inget etiskt tillstånd sökas. Makar och kvinnliga vårdtagare

\footnotetext{
1 Förkortningen "N" används istället för närståendevårdarens namn i citaten.
}

är överrepresenterade i den här studien, medan vårdtagare med minnessjukdomar är exkluderade trots att det är en vanlig grupp vårdtagare i närståendevård (SHM 2014). Denna skevhet i representationen av äldre närståendevårdtagare samt det ringa antalet informanter innebär att resultaten inte bör generaliseras. Istället bidrar denna fallstudie med subjektiva upplevelser av en hittills relativt outforskad målgrupp, det vill säga närståendevårdtagare.

Livsloppsperspektivet används i analysen som ett redskap för att förstå materialet, men teorin användes också i intervjuguiden genom att till exempel be respondenterna berätta om sitt liv. Intervjuguiden inkluderade den direkta frågan om varför vårdtagarna valt närståendevård istället för någon annan vårdform, men det är främst från svaren på övriga frågor som analysen härstammar. Genom att dels studera vårdtagarnas bakgrund, dels den samhällsutveckling som vårdtagarna som generation upplevt samt speciellt genom att inkludera dagens äldreomsorg som en kontext, har vi analyserat vårdtagarnas resonemang kring sina vårdval utgående från livsloppsperspektivet. Vi utgår från att det levda livsloppet påverkar äldre individers vårdval genom normer, värderingar och resurser i form av ekonomi, den anhörigas ork och boendemiljö, samtidigt som livsloppet utspelar sig i ett visst samhälle med specifika möjligheter och begränsningar. Alla dessa faktorer bildar tillsammans en kontext för vårdtagarnas val och handlingar gällande sina vårdarrangemang. Livsloppsperspektivet möjliggör att vi kan förstå subjektiva upplevelser om hur äldre vill bli vårdade och vilka valmöjligheter de upplever sig ha.

\section{Resultat}

Underkategorier som tas upp i den här omarbetade analysen är: obälsa som en gemensam vändpunkt, närståendevård som ett självklart val och framtidens ovisshet. I den första underrub- 
riken analyseras uppkomsten av vårdbehovet och vårdsituationen som en bakgrund till vårdvalet. I den efterföljande delen analyseras valet av närståendevård med vårdtagarnas personliga motiv och speciellt den övriga äldreomsorgen som kontext. Slutligen behandlas informanternas syn på det fortsatta livsloppets vårdarrangemang.

\section{Ohälsa som en gemensam vändpunkt}

Enligt livsloppsperspektivet är det viktigt att studera viktiga vändpunkter $i$ en individs livslopp och även att ta i beaktande när vändpunkten inträffat (Elder Jr., Kirkpatrick Johnson \& Crosnoe 2003). Att bli vårdtagare kan klassificeras som en viktig vändpunkt i livet, även om ohälsa i hög ålder inte alltid innebär en enskild sjukdom eller plötslig händelse. Vårdbehovet kan också vara en följd av en allmänt försämrad funktionsförmåga som uppstått under en längre tid. Att bli vårdtagare som äldre är en speciell fas i jämförelse med när ett vårdbehov uppstår i andra åldrar, eftersom en äldres vårdbehov sällan förutspås försvinna (Zechner 2008). För informanterna i vår studie kan närståendevård ses som ett sätt att förlänga det "normala" tidigare livsloppet trots en försämrad hälsa. Genom att fortsätta bo hemma och vara tillsammans med vårdaren förlängs den tidigare livsstilen $i$ viss mån, för både vårdtagaren och vårdaren.

Det var ju helt naturligt det att jag ville vara hemma. Inte ville jag börja ligga på någon anstalt. Det ville inte hon heller. (Informant 4)

Samtliga vårdtagare i studien behövde mångsidig hjälp i vardagen, vilket ofta är ett kriterium för att vårdtagarens anhöriga ska få ingå ett närståendevårdavtal. Hur och när vårdtagarnas vårdbehov hade uppstått varierade. För de flesta informanterna hade den allmänna funktionsförmågan försämrats gradvis, även om det ofta var något speciellt som hade utlöst vårdbehovet till exempel en stroke eller en fraktur.
En respondent som slutligen blivit blind efter flera decennier av långsam försämring av synen ansåg att hon accepterade sin situation bättre än många andra synskadade eftersom försämringen skett gradvis.

För en kvinnlig respondent hade vändpunkten inträffat redan $i$ ungdomen. Hon blev förlamad i tjugoårsåldern. Kvinnan berättade att hon i början trodde att förlamningen var temporär men att den sedan visade sig vara bestående. Denna kvinnas livslopp skiljer sig därmed markant från de andra vårdtagarna eftersom hon varit vårdtagare i merparten av sitt liv.

$\mathrm{N}$ jobbade men han hade ju mig sedan, nätter och... Och han har inte skilt sig (skratt). Konstigt. Fast de skiljer sig allihop. (Informant 1)

Kvinnans tacksamhet över att närståndevårdaren inte velat skilja sig trots alla år som vårdare framgår i citatet ovan. Vårdtagarens ohälsa innebär nämligen stora förändringar också för den anhöriga som bland annat får en ny roll som närståendevårdare. Rollen kan komma stegvis eller plötsligt men oavsett påverkas parternas tidigare rutiner och gemensamma livsstil av vårdbehovet. En informant beskriver den förändrade vardagen som något varken hon eller närståendevårdaren kunnat förvänta sig.

Och sen när $\mathrm{N}$ hör att jag smäller, så då vet han ju att jaha, nu ligger jag på golvet. Så då kommer han och lyfter upp mig. Men att de här sista åren skulle vara så här eländiga så det har nog varken han eller jag fantiserat. (paus). För att vi har ju varit väldigt aktiva. (Informant 5)

\section{Närståendevård som ett självklart val}

Närståendevård som vårdform upplevdes av vårdtagarna som ett självklart val: ett val som inträffat så gott som automatiskt. Att vårdtagarna upplevde valet som naturligt uttrycktes 
bland annat i form av att en del respondenter upplevde att det knappt behövdes någon förklaring till varför man valt vårdformen. Liknande resultat återfinns i Miettinens (2012) studie om vårdstrategier bland föräldrar som är närståendevårdare till vuxna barn med intellektuella funktionsnedsättningar. Miettinen (2012) konstaterar att bakom upplevelsen av det "naturliga" med närståendevård återfinns ofta normer såsom till exempel det finländska samhällets förväntningar på att föräldrar tar hand om sina barn. Normen förstärks ytterligare i och med bristande offentlig servicestruktur.

Att vårdtagarna $i$ vår studie hyser normer om att det hör till att ställa upp för varandra syns i en kvinnlig vårdtagares berättelse om hur hennes make initialt inte ville bli kallad för "vårdare" trots att han inte hade något emot att utföra själva vården. Han ville hellre utföra omsorgen utan hjälp utifrån. Till sist gick mannen med på att ingå ett närståendeavtal med kommunen efter vårdtagarens påtryckningar i kombination med ekonomiska skäl.

Det var kanske för det där med hjälp utifrån, men också p.g.a. ordet, vårdare. (skratt). Men jag sa att han måste ju iallafall hjälpa hela tiden, han måste handla och ska någonting ut, det är ju han som gör det, ja, jag vet inte. Så det var mest det där namnet. Men nu inser han att det är bra att få pengarna. För vi har ju inte så höga pensioner, utan det är ju mest det där vanliga. Man har ju inte det då man har varit själv, egenföretagare. Så nog är det bra. (Informant 3)

Informanterna är födda på 1930- och 1940-talet vilket innebär att de har växt upp i en efterkrigstid då den finländska välfärdsstaten ännu inte var uppbyggd (Anttonen 2009). En vårdtagare beskrev uppväxtåren som en tid "då det inte fanns någonting”. En annan informant berättade att framtiden var väldigt oviss och att socialarbetet var outvecklat. Det var därför vanligt att man hjälptes åt och tog hand om till exempel äldre grannar, vilket flera res- pondenter hade bevittnat eller själva varit med om. Vårdtagarna i vår studie kan hysa normer om att det hör till att ställa upp för varandra, dels som en följd av den långa relationen med vårdaren men också som en följd av generationstillhörigheten och den samhällsutveckling de upplevt, inte minst gällande äldreomsorgen. Samtidigt som närståendevård sågs som något naturligt hos informanterna, var det inte något som alla tog för givet. Flera uttryckte stor tacksamhet mot vårdaren. Förut var vårdoch hushållsarbete traditionella kvinnosysslor (Anttonen \& Zechner 2009), men samtliga informanter var medvetna om att situationen idag är annorlunda. Både de manliga och kvinnliga vårdtagarna ville utföra hushållsarbete efter förmåga vilket vittnar om att deras attityder ändrat med åren och med situationen.

På samma sätt som vårdtagarna upplevt en tid då den finländska välfärdsstaten ännu inte var utvecklad, har vårdtagarna även sett äldreomsorgen när den varit som mest generös. De visste att hemvården tidigare var mer omfattande än den är idag. Den offentliga hemvården i Finland riktade sig på 1970- och -80-talen till en stor del av finländare över 65 år och personalen utförde både hushållsarbete och personlig omvårdnad, men sen 1990talet har hemvården skurits ner och omorganiserats (Kröger \& Leinonen 2012). Idag riktas hemvården enbart till äldre med störst vårdbehov och fokus är på personlig omvårdnad istället för hushållstjänster. Hemvården har därför blivit mer fragmenterad och det medför att äldre och deras anhöriga får koordinera sina tjänster i ett allt mer komplext system för att alla behov ska bli tillgodosedda (Anttonen \& Häikiö 2011). Majoriteten av informanterna hade personliga erfarenheter av dagens hemvård och ansåg att personalen byts ut för ofta och att de har tidsbrist. En informant var missnöjd med att hemvårdspersonalen inte städar längre, eftersom det var just den biten hon mest önskade hjälp med. Hon konstaterade att besöken var väldigt korta då hennes medicinering sköttes av hemvården under en tillfällig period. 
Kvinnan jämförde sin erfarenhet av hemvården med hur det fungerade då hennes förälder fick vård då servicesystemet ännu var mer omfattande.

Ja, de var bara in och gav mig (medicinen), och pratade några ord och sen iväg. Det är ju synd, annat var det när mamma hade, de gjorde allt. (Informant 6)

En informant upplevde frustration över bristande kontinuitet $\mathrm{i}$ hemvården. Hon konstaterade att så fort en patrull har lärt sig rutinerna så byts patrullen ut mot en ny. På så sätt avbryts klientens invanda rutin och vardagen ändrar igen.

Men nog förstår man ju de här närvårdarna, vad skulle de kunna och de byts så ofta. Då man har kommit in i det, då de har lärt sig och vet, så då har de ställt om någonting, de hade någon patrull kallas det som var här då i början, och när de var inne i "rulten" så då skulle det upphöra. Så då kom jag till en annan grupp som skulle lära sig. Det tar ju tid innan de vet hur de ska göra. Somliga har inte sett liften förr och hur de ska göra med den. (Informant 1)

Informanterna jämförde ofta närståendevård med hemvård och ansåg att det fanns många praktiska fördelar med närståendevård, såsom att vårdaren visste var saker och ting fanns $i$ hemmet och att vårdaren visste vad vårdtagaren klarade och inte klarade av. Dessutom innebar närståendevård att närståendevårdaren fanns tillhands hela tiden till skillnad från hemvårdspersonalen.

Man får hjälp då man behöver. (Informant 2)

Förutom den ständiga tillgängligheten uppskattades också närståendevårdarens kännedom om vårdtagarens behov. En informant konstaterade att hon till sin närståendevårdare bara behövde säga ett ord så förstod vårdaren hur han skulle göra, medan hemvårdspersonalen behövde mer direktiv. De praktiska fördelarna med närståendevård kompletterades även av andra trygghetsaspekter. En informant konstaterade att hon inte skulle kunna lita på någon utomstående på samma sätt som hon litade på sin närståendevårdare, medan en annan kvinnlig informant ansåg att hon inte kunde vara sig själv i främmande vårdares sällskap.

Så klart det är bättre om det är $\mathrm{N}$ hela tiden. Men han kan ju inte med såren åtminstone. Så ibland sitter man nog så vint och snett, men han får ju fixa till det han då de har gått. Så får jag vara arg på honom (skratt). (Informant 1)

I citatet ovan framgår det att informanten inte vågade säga åt den utomstående vårdpersonalen att de hade placerat henne dåligt. Istället tog hon ut sin frustration på närståendevårdaren. Samtidigt konstaterade vårdtagaren i samma citat att närståendevårdaren inte kunde hantera hennes sår, eftersom han saknade de rätta yrkeskunskaperna om hur han skulle sköta dem. Närståendevård erbjuder en annan kontinuitet i vården än vad hemvården gör eftersom vårdaren alltid är densamma, men samtidigt uttryckte flera informanter uppskattning över att vårdas av någon som var utbildad inom hälso- och sjukvård.

\section{Framtidens ovisshet}

Det fortsatta livsloppet oroade informanterna i varierande utsträckning, eftersom de visste att det var oundvikligt att vårdarrangemangen skulle behöva ändras förr eller senare som en följd av antingen vårdarens eller vårdtagarens ohälsa. En del vårdtagare försökte underlätta den anhörigas vårdbörda för att göra den nuvarande vårdsituationen mer hållbar. En informant konstaterade att hon inte ville vara till besvär mer än nödvändigt. Det innebar till exempel att hon som tyckte om levande ljus valde att inte be vårdaren tända dessa, efter- 
som det innebar extra arbete för honom. En annan informant uppgav att han tänkte på närståendevårdarens arbetsbörda då han åkte in på intervallvård regelbundet för att avlasta frun. När han hade varit hemma en längre tid tog nämligen hennes ork slut. Utmattning är som tidigare nämnt ett välkänt problem inom närståendevård (SHM 2014). Genom att hitta strategier för att klara sig i vardagen kan parets gemensamma livslopp förlängas.

Det fungerar bra det här. Inte... Men... Det är ju som jag brukar säga åt $\mathrm{N}$ att vi ska vara snälla med varandra så orkar vi nog. Ja. Men nog är det, nog fungerar det så här. Det är ju nog turvis så att rösten är hög här. Så då kan jag ropa till och säga "hur fan ska vi få slut på det här nu”. (Informant 4)

Flera informanter funderade på att flytta i framtiden men det upplevdes som besvärligt och något som de helst drog ut på. Samtidigt var det i flera fall redan för tungt för vårdaren att ta hand om vårdtagaren, gården och huset. Ett par hade valt att flytta tillsammans till ett servicehus för att inte behöva ta hand om egnahemshuset. På servicehuset fanns dessutom personal på plats och de använde sig av ett trygghetslarm. Det kan ses som ett exempel på en strategi som dyaderna använder sig av för att kunna fortsätta bo tillsammans. Vårdarens ork oroade informanterna, eftersom flera närståendevårdare hade egna hälsoproblem. Närståendevårdarna var dessutom jämngamla eller äldre än vårdtagarna. De flesta informanter upplevde därför att vårdarens ork redan hade blivit sämre och det väckte oro inför framtiden.

Och $\mathrm{N}$ orkar inte så mycket som han orkade förut. Så tänker man ju nog att vart kommer man sedan. (paus) Inte skulle man ju vilja ligga på någon åldersanstalt. Men dit kommer jag ju då inte han orkar sköta något mer. För inte tycks jag dö, brukar jag säga (skratt). (Informant 1 )
I citatet ovan där informanten å ena sidan var humoristisk och å andra sidan allvarlig, kan man tolka det som att informanten hellre skulle dö än att åka in på en institution. Rädslan för att bo på institution framgår i flera citat. Det är möjligt att äldres tankar om boendemiljö påverkas av den starka rådande kvarboendeprincipen på nationell nivå där målsättningen är att alltfler ska åldras hemma (SHM 2017). Vårdpreferenserna kan också påverkas av media och andras berättelser om dålig vårdkvalitet i äldreomsorgen (Gunnarsson 2009). Att få vård i hemmet istället för på en institution kan ses som ett sätt att behålla kontrollen och vara på sitt eget "revir" trots att man är beroende av hjälp från andra (Twigg 2000). Pirhonen (2017) har studerat ett gott liv bland äldre vårdtagare på serviceboenden. Klienternas värdighet och identitet tryggades med hjälp av bland annat upprätthållande av livslånga vanor och beaktande av personliga önskemål, medan standardiserad behandling och resursbrist påverkade klienterna negativt. Det är troligt att deltagarna $\mathrm{i}$ vår studie upplever att deras identitet och värdighet är bättre tryggad i närståendevård i jämförelse med andra vårdformer, eftersom deras unika livslopp syns mera i den personcentrerade vårdformen som närståendevård är. Pirhonens (2017) studier om identitet på serviceboenden kan även kopplas till de tidigare nämnda svenska studierna om äldres vårdpreferenser där deltagarna upplevde en rädsla för att känna sig identitetslösa (Harrefors, Sävenstedt \& Axelsson 2009). Beroende på boendetyp finns det även en risk för att vårdtagarna $\mathrm{i}$ vår studie $\mathrm{i}$ framtiden inte skulle kunna bo med sin vårdare längre. På det sättet skulle parets gemensamma livslopp genomgå en potentiellt ännu större vändpunkt än hittills.

\section{Diskussion}

I den här studien har äldre närståendevårdtagares tankar om sina vårdarrangemang stud- 
erats ur ett livsloppsperspektiv. Resultaten i vår studie visade att vårdtagarnas val av närståendevård påverkas av flera olika faktorer. Närståendevård innebär en förlängning av den tidigare livsstilen $\mathrm{i}$ viss mån då vårdtagaren får fortsätta bo hemma tillsammans med sin partner eller anhöriga trots en försämrad funktionsförmåga. Närståendevård innebär också att vårdtagaren kan lita på att få vård när hon eller han behöver det, vilket har ett samband med både den nära relationen och de praktiska arrangemangen. Vårdtagarna upplever delvis att det är naturligt att ställa upp för varandra, samtidigt som de känner en stor tacksamhet gentemot närståendevårdaren och oroar sig för dennes hälsa. Vårdtagarna är uppväxta i ett Finland där välfärdsstaten ännu inte var uppbyggd och det var vanligt att man istället fick hjälpas åt, samtidigt som de också bevittnat den finländska välfärdsstatens och äldreomsorgens glansdagar.

Den viktigaste faktorn för vårdtagarnas vårdval tycks ändå vara deras erfarenheter och/ eller föreställningar av den nutida äldreomsorgen. Den formella hemvården upplevs som otrygg eftersom personalen hela tiden byts ut och har för bråttom. Institutionsvård upplevs av vårdtagarna i studien som ett ännu sämre alternativ. Det leder till en oro för framtida vårdarrangemang, eftersom vårdtagarna vårdas av jämnåriga anhöriga med begränsad ork.

Den finländska äldreomsorgen omorganiseras som en följd av demografiska och politis$\mathrm{ka} \mathrm{krav}$ på nationalekonomiska vårdlösningar. Närståendevård utmålas som en möjlig lösning och regeringen har som målsättning att utöka vårdformen. Äldre vårdtagare och speciellt närståendevårdtagare förbises ofta i forskning och det finns ett behov av att närmare studera omorganiseringarnas konsekvenser för dem som de främst berör. Studiens viktigaste bidrag är att lyfta fram äldre närståendevårdtagares röst, eftersom de är en relativt understuderad målgrupp. Kunskap om äldre vårdtagares situation behövs för att kunna utveckla närståendevården och annan äldreomsorg. Vård är en kom- plex och emotionell process för både vårdtagaren och vårdaren. Vem som utför vården och under vilka omständigheter har stor betydelse för vårdtagarens välbefinnande.

I vår studie har vi valt att tillämpa livsloppsperspektivet för att fånga och analysera äldre närståendevårdtagares resonemang kring sina vårdval. Livsloppsperspektivet har möjliggjort en förståelse av vårdtagarens bakgrund som en kontext till valet av närståendevård. Erfarenheter av äldreomsorgens utveckling har diskuterats $\mathrm{i}$ intervjuerna och vårdtagarna har utmålat brister i dagens formella äldreomsorg som en viktig bidragande orsak till deras val av närståendevård. Närståendevård uppfyller emellertid många andra funktioner förutom att fungera som ett alternativ till mindre lockande möjligheter. Närståendevården möjliggör i bästa fall en känsla av trygghet och kontroll, det vill säga ett sätt att förlänga det vanliga, önskvärda livet i så stor omfattning som möjligt trots att funktionsförmågan försämrats. Samtidigt är det en tidsfråga innan vårdsituationen ändras eftersom både vårdtagaren och vårdaren blir äldre och risken för ohälsa ökar. Närståendevårdtagarnas oro för framtida vårdarrangemang vittnar om problem i den finländska äldreomsorgen. Vårdtagarna som hade erfarenhet av hemvård upplevde stora brister i kontinuitet och resursomfattning. Närståendevård borde både för vårdtagares och anhörigas skull vara ett frivilligt val och inte basera sig på att den formella vården fungerar bristfälligt. Närståendevård är inte heller ett alternativ för alla äldre eftersom vårdformen förutsätter att det finns en potentiell närståendevårdare i den äldres sociala nätverk.

Subjektiva upplevelser av närståendevårdtagare kan berätta något viktigt om hur välfärden och äldreomsorgen fungerar i dagens Finland. Samtidigt går det inte att generalisera äldre finländares vårdpreferenser baserat på sju röster. Vårdtagarna $\mathrm{i}$ den här studien var nöjda med närståendevård och det är troligt att sådana respondenter är lättare att nå än närståendevårdtagare som är missnöjda med 
sin vård. Närståendevårdarens närvaro vid flera intervjuer kan ha påverkat resultaten i viss mån. I fortsatt forskning kunde närståendevårdaren och vårdtagaren intervjuas samtidigt men separat för att undvika att båda parterna oavsiktligt deltar i samma intervjutillfälle. I framtiden borde äldres vårdpreferenser och erfarenheter studeras i större utsträckning för att trygga välfärden och utveckla tjänster som motsvarar målgruppens önskemål och behov. Uppföljningsstudier kunde göras med närståendevårdtagare och/eller närståendevårdare för att studera hur livssituationen utvecklas vartefter vårdtagarens vårdbehov ändras eller närståendevårdarens hälsa försämras.

Sammanfattningsvis visade vår studie att vårdtagarna upplevde många fördelar med närståendevård, samtidigt som de hade delvis negativa erfarenheter och föreställningar av annan äldreomsorg. Vårdtagarna oroade sig för på vilket sätt de framtida vårdbehoven skulle tryggas då närståendevård inte längre är möjligt. Att studera äldres vårdval utgående från livsloppsperspektivet möjliggör en nyansrik analys och kopplar ihop individens personliga resonemang kring hur hon vill bli vårdad med äldreomsorgens praktiska möjligheter respektive begränsningar.

\section{Kontakt:}

Sarah Åkerman, PM, Doktorand

Socialpolitik, Fakulteten för Pedagogik och välfärdsstudier, Åbo Akademi, Vasa epost: sarah.akerman@abo.fi

\section{NOT}

$\mathrm{Vi}$ vill tacka redaktören och granskarna för deras kommentarer under granskningsprocessen. Vi tackar även Svenska Kulturfonden och Waldemar von Frenckells stiftelse för finansiering av arbetet med studien.

\section{Litteratur}

Alley, D. E., Putney, N. M., Rice, M. \& Bengtson, V. L. (2010). The increasing use of theory in social gerontology: 1990-2004. Journal of Gerontology: Social Sciences, 65(5), 583-590. doi: 10.1093/geronb/gbq053

Anttonen, A. (2009). Hoivan yhteiskunnallistuminen ja politisoituminen. I Anttonen, A., Valokivi, H. \& Zechner, M. (red.). Hoiva. Tutkimus, politiikka ja arki (s. 54-93). Tallinn: Vastapaino.

Anttonen, A. \& Zechner, M. (2009). Tutkimuksen lähestymistapoja hoivaan. I Anttonen, A., Valokivi, H. \& Zechner, M. (red.). Hoiva. Tutkimus, politiikka ja arki (s. 16-53). Tallinn: Vastapaino.

Anttonen, A. \& Häikiö, L. (2011). From social to active citizenship? Tensions between policies and practices in Finnish elder care. I Tonkens, E. \& Newman, J. (red.), Summoning the active citizen: responsibility, participation and choice in Western Europe (s. 67-86). Amsterdam: Amsterdam University Press.

Anttonen, A. \& Meagher, G. (2013). Mapping marketisation: concepts and goals. I Meagher, G. \&
Szebehely, M. (red.). Marketisation in Nordic elder care: a research project on legislation, oversight, extent and consequences (s. 13-22). Stockholm: Stockholms Universitet.

Bryman, A. (2011). Sambällsvetenskapliga metoder. (2., [rev.] uppl.) Malmö: Liber.

Dunér, A. (2007). To maintain control. Negotiations in the everyday life of older people who can no longer manage on their own. Göteborg: Göteborgs Universitet.

Elder G. H., Johnson, M. K. \& Crosnoe, R. (2003). The emergence and development of life course theory. I Mortimer, J. T. \& Shanahan, M. J. (red.) Handbook of the Life Course (s. 3-19). Boston: Springer.

Esaiasson, P., Gilljam, M., Oscarsson, H. \& Wägnerud, L. (2007). Metodpraktikan - Konsten att studera sambälle, individ och marknad. Stockholm: Norstedts Juridik.

Folkhälsan [u.å.]. Om Folkhälsan. Hämtad 11 augusti, 2017 från:

https://www.folkhalsan.fi/om-folkhalsan/ 
Gunnarsson, E. (2009). The welfare state, the individual and the need for care: older people's views. International Journal of Social Welfare, 3(18), 252259. doi: 10.1111/j.1468-2397.2008.00610.x

Harrefors, C., Sävenstedt, S. \& Axelsson, K. (2009). Older people's perceptions of how they want to be cared for: an interview study with healthy older couples in Northern Sweden. Scandinavian Journal of Caring Sciences, 23(2), 353-360. doi: 10.1111/j.1471-671 2.2008.00629.x

Häikiö, L., Anttonen, A. \& Van Aerschot, L. (2011). Vastuullinen ja valitseva kansalainen: vanhushoivapolitiikan uusi suunta. Yhteiskuntapolitiikka, 76(3), 239-250. Hämtad 2.2.2017 från: http://urn.fi/URN:NBN:fi-fe201209117832

Institutet för hälsa och välfärd. (2017). Antalet klienter inom hemvården har ökat medan personalen har minskat. Hämtad 25.4.2017 från: ttps://www.thl. fi/sv/web/thlfi-sv/-/antalet-klienter-inom-hemvarden-har-okat-medan-personalen-har-minskat

Karsio, O. \& Anttonen, A. (2017). 2010-luvun vanhushoivaa - julkisen ja yksityisen risteyskohdissa. Pääkirjoitus. Gerontologia, 31(3), 161-164. Hämtad 27.10.2017 från: https://journal.fi/gerontologia/article/view/65949.

Kröger, T. \& Leinonen, A. (2012). Transformation by stealth: the retargeting of home care services in Finland. Health E Social Care in the Community, 20(3), 319-327. doi:10.1111/j.1365-2524.2011.01047.x

Kvale, S. \& Brinkmann, S. (2009). Den kvalitativa forskningsintervjun. 2 uppl. Lund: Studentlitteratur.

Lag om stöd för närståendevård. 2.12.2005/937

Linnosmaa, I., Jokinen, S., Vilkko, A., Noro, A. \& Siljander, E. (2014). Omaishoidon tuki. Selvitys omaishoidon tuen palkkioista ja palveluista kunnissa vuonna 2012. Hämtad 2.2.2017 från: http:// www.julkari.fi/bitstream/handle/10024/125550/ URN_ISBN_978-952-302-144-0.pdf?sequence $=1$

Mayer, K. U. (2009). New directions in life course research. Annual Review of Sociology, 35(1), 413433. doi: 10.1146/annurev.soc.34.040507.134619

Miettinen, S. (2012). Family care of adults with intellectual disabilities: analysis of finnish policies and practices. Journal of Policy and Practice in Intellectual Disabilities, 9(1), 1-9. doi: 10.1111/j.1741-1130.2012.00328.x.
Pirhonen, J. (2017). Good human life in assisted living for older people. What the residents are able to do and be. Tampere: Tampere University Press.

Puthenparambil,J. M., Kröger, T. \& Van Aerschot, L. (2015). Users of home care services in a nordic welfare state under marketisation: the rich, the poor and the sick. Health and Social Care in the Community, 25(1), 54-64.

doi: $10.1111 /$ hsc. 12245

Social- och hälsovårdsministeriet. (2014). Kansallinen omaishoidon kehittämisohjelma. Sosiaali- ja terveysministeriön raportteja ja muistioita 2014:2. Hämtad 12.3.2017 från: http://julkaisut.valtioneuvosto.fi/bitstream/handle/10024/70270/ URN_ISBN_978-952-00-3483-2.pdf?sequen$\mathrm{Ce}=1$

Social- och hälsovårdsministeriet. (2016a). Kuntainfo: Omaishoidon tuen hoitopalkkiot vuonna 2017. Hämtad 4.4.2017 från: http://stm.fi/artikkeli/-/asset_publisher/kuntainfo-omaishoidon-tuen-hoitopalkkiot-vuonna-2017

Social- och hälsovårdsministeriet. (2016b). Spetsprojekt. Hemvården för äldre utvecklas och vården för alla ålderskategorier förbättras. [Projektplan]. Hämtad 1.2.2017 från: http://julkaisut.valtioneuvosto.fi/bitstream/handle/10024/75307/ RAP_2016_49_Hemv\%C3\%A5rdenF\%C3\% B6r.pdf?sequence $=1$

Social- och hälsovårdsministeriet. (2017). Kvalitetsrekommendation för att trygga ett braåldrande och forrbättra servicen 2017-2019. Social- och hälsovårds publikationer 2017:7. Hämtad 10.4.2018 från: http://urn.fi/URN:ISBN:978-952-00-3961-5

Sointu, L. (2016). Hoiva subteessa. Tutkimus puolisoaan hoivaavien arjesta. Tampere: Tampere University Press.

Szebehely, M. \& Meagher, G. (2013). Four Nordic countries - four responses to the international trend of marketization. I Meagher, G. \& Szebehely, M. (red.). Marketisation in Nordic elder care: a research project on legislation, oversight, extent and consequences (s. 241-284). Stockholm: Stockholms Universitet.

Twigg, J. (2000). Bathing - The Body and Community Care. London: Routledge.

Ulmanen, P. \& Szebehely, M. (2015). From the state to the family or to the market? Consequences of reduced residential care in sweden. International Journal of Social Welfare, 24(1), 81-92. doi: 10.1111/ijsw.12108 
Van Aerschot, L. (2014). Vanhusten hoiva ja eriavoisuus, sosiaalisen ja taloudellisen taustan ybteys avun saamiseen ja palvelujen käyttöön. Tammerfors: Tampere University Press.

Vilkko, A., Muuri, A., Saarikalle, K., Noro, A., FinneSoveri, H. \& Jokinen, S. (2014). Läheisavun moninaisuus. I Vaarama, M., Karvonen, S., Kestilä, L., Moisio, P. \& Muuri, A. (red.) Suomalaisten byvinvointi. 2014 (s. 222-237). Helsingfors: Institutet för hälsa och välfärd.

Vård- och landskapsreformen. (u.å.). Allmän presentation av social-och hälsovårds-och landskapsrefor- men. Hämtad 27.10.2017 från: http://alueuudistus.fi/sv/allman-information

Zechner, M. (2008). Kykyjä kyvyttömyyden tasolla: hoivan vaiheet vanhusten kertomana. Janus, 16(4), 295-310. Hämtad 27.5.2017 från: https:// journal.fi/janus/article/view/50488>.

Zechner, M. \& Valokivi, H. (2009). Hoivan tarve ja vanhan ihmisen toimintakyky. I Anttonen, A., Valkokivi, H. \& Zechner, M. (toim.) Hoiva. Tutkimus, politiikka ja arki (s. 154-175). Tallinn: Vastapaino. 